\title{
SZKOLNICTWO BARTOLOMITÓW NA ZIEMIACH POLSKICH NA PRZYKLADZIE SEMINARIÓW W WĘGROWIE, KIELCACH I SANDOMIERZU. ZARYS PROBLEMATYKI
}

\begin{abstract}
Streszczenie
Założycielem Instytutu Księży Życia Wspólnego zwanych potocznie bartolomitami, bartoszkami lub komunistami, którego konstytucje zostały zatwierdzone 7 lipca 1680 r. przez Innocentego XI, był Bartłomiej Holzhauser. Cechami charakterystycznymi Instytutu były zakładanie seminariów i duża dbałość o poziom kształcenia alumnów. Bartolomici do Polski zostali sprowadzeni przez króla Jana III Sobieskiego. Fundacje Jana Dobrogosta Krasińskiego na rzecz bartolomitów w Węgrowie uczyniły z tego miasta centralny ośrodek działalności Instytutu. To właśnie z seminarium węgrowskiego bartolomitów pochodziła znaczna część kadry prowadzącej seminarium duchowne w Kielcach, w XIX wieku zaś bartolomici z seminarium kieleckiego stanowili trzon nowo tworzonego seminarium sandomierskiego. Kres działalności Instytutu Księży Życia Wspólnego nastąpił w połowie XIX wieku.
\end{abstract}

Słowa kluczowe: bartolomici; Instytut Księży Życia Wspólnego; seminarium duchowne; Węgrów

\section{Instytut Księży Życia Wspólnego - księża kommuniści zwani bartolomi- tami, bartoszkami}

Instytut Księży Życia Wspólnego (Institutum Clericorum Saecularium in Communi Viventium) został założony w latach 40. XVII wieku przez Bartłomieja Holzhausera, urodzonego w 1613 r. we wsi Langenau, w okręgu Ulm. Studiował on na uniwersytecie jezuickim w Inglostadt. Konstytucje Instytutu zostały zatwierdzone 7 lipca 1680 r. przez Innocentego XI. Księży należących do tej instytucji potocznie nazywano - od imienia założyciela - bartolomitami ${ }^{1}$.

\footnotetext{
* Wojciech Jerzy Górczyk - mgr historii, kustosz w Muzeum Romantyzmu w Opinogórze e-mail: w.gorczyk@onet.eu https://orcid.org/0000-0001-5068-2589
} 
Bartłomiej Holzhauser w wielu aspektach wzorował swój instytut na jezuitach. Przełożony generalny bartolomitów, podobnie jak u jezuitów, był wybierany dożywotnio i również bartoszkowie byli zobowiązani do corocznych rekolekcji². Bartłomiej Holzhauser opublikował Ustawy i ćwiczenia duchowe dla księży instytutu, wspólnie żyjących, inspirowane Ć wiczeniami duchowymi Ignacego Loyoli, założyciela jezuitów. Swoje nauczanie bartolomici w większości również opierali na systemie jezuitów, korzystając z ich podręczników, szczególnie jeżeli chodzi o filozofię. Bartoszkowie nie byli zakonem, ale instytutem, nie składali więc ślubów zakonnych, a jedynie przyrzeczenie wytrwania w Instytucie do śmierci ${ }^{3}$. Można przypuszczać, że zwolnienia z tego przyrzeczenia nie były rzadkością. Wiadomo, że z Instytutu w Polsce odeszli, stając się księżmi diecezjalnymi, np. Franciszek Erazm Preiss ok. 1770 r., Franciszek Ksawery Szaniawski ok. 1803 r. ${ }^{4}$ Bartolomici nie będąc zakonnikami, mogli - zgodnie z breve Innocentego XI - sprawować wszelkie godności kościelne, nadal pozostając członkami Instytutu ${ }^{5}$.

Instytut Księży Życia Wspólnego posiadał specyficzną strukturę. Na jego czele stał prezes generalny, w prowincji zaś prezydent zwany też prezesem (prowincjał). Jednak to biskup decydował, gdzie będą pracować członkowie Instytutu, zarówno proboszczowie, jak i wikariusze. W jednej parafii mogli być jednocześnie księża diecezjalni i bartoszkowie. W takiej sytuacji zdarzało się, że księża diecezjalni starali się o przyjęcie do Instytutu bartolomitów. Świadczy o tym dokument z 29 listopada 1824 r., w którym Wojciech Janecki, osadzony jako wikariusz przez biskupa krakowskiego przy kolegiacie w Kielcach, gdzie wikariuszami byli bartolomici, usilnie zabiegał o przyjęcie do Instytutu, prosząc nawet o zatwierdzenie decyzji biskupa przez prezydenta bartolomitów: ,[...] nie chcąc się odznaczać od innych [...] K.K. Wikaryuszów Kiel[eckich], którzy z mocy Instytucyi Prezesa Kommunistów ten Wikryat otrzymali" ". Nie jest znana odpowiedź na prośbę W. Janeckiego, ale z tego samego pisma można dowiedzieć się, że była to już jego druga prośba o przyjęcie do bartoszków. Wcześniej chciał objąć wikariat w Żarnowie również jako bartolomita. W tym wypadku oznaczało to zmianę diecezji przez W. Janeckiego. Parafia w Żarnowie należała do utworzonej w 1818 r. diecezji sandomierskiej. Prezes Instytutu zaakceptował prośbę, ale z zastrzeżeniem, że proszący musi uzyskać zgodę swojego ordynariusza. Wiadome jest, że takiej zgody odmówił W. Janeckiemu zarówno konsystorz, jak i biskup, osadzając go na wikariacie w Grodźcu (dekanat siewierski) ${ }^{7}$. Nie wiadomo, czy taka sama zgoda

${ }^{1}$ J. Górka, Żywot i dzieła wielebnego stugi bożego Bartłomieja Holzhausera, Tarnów 1908, s. 47

${ }^{2}$ Tamże, s. 54.

${ }^{3}$ Tamże, s. 47.

${ }^{4}$ D. Krześniak-Firlej, W. Firlej, Bibliografia piśmiennictwa zakonników z sekularyzowanych klasztorów działających na obszarze diecezji kieleckiej i sandomierskiej w XIX w., „Hereditas Monasteriorum", 8 (2016) s. 163.

${ }^{5}$ Górka, Żywot i dzieła, s. 220.

${ }^{6}$ Archiwum Diecezjalne w Drohiczynie (dalej: ADD), ZAKWZ, sygn. VII/C/1, Korespondencja urzędowa księży wspólnego życia 1682-1861, k. 28.

${ }^{7}$ Tamże. 
była potrzebna W. Janeckiemu i w tym wypadku, skoro teraz chciał pozostać na wikariacie, na którym osadził go biskup. Wydaje się jednak, że słuszne byłoby założenie, iż analogicznie jak w przypadku zakonów przyjęcie do Instytutu kommunistów księdza diecezjalnego wymagało zgody biskupa ordynariusza w każdym wypadku.

W każdej diecezji, w której działali bartolomici, zakładane było przez nich seminarium dla kandydatów na księży i dom księży emerytów. Pod tym względem byli prekursorami, właściwie dzisiejsza organizacja diecezji jest w dużej mierze wzorowana na organizacji księży bartolomitów i, jak można przeczytać w Encyklopedii kościelnej, „,dzisiejsze seminaria puerorum powstały z naśladowania jego instytucji" ", to samo tyczy się domów dla księży emerytów, które obecnie są niemal w każdej diecezji. Strojem bartolomitów była sutanna księży diecezjalnych, pod sutanną nosili krzyż (podobnie jak jezuici), nie zakładali klasztorów, ale mieszkali na plebaniach. W parafiach bartoszkowie żyli wspólnie, przeznaczając część dochodów na wspólne wydatki i utrzymanie seminariów oraz domów dla księży emerytów, a część zatrzymywali dla siebie9 . Byli zobowiązani do odprawiana corocznych rekolekcji i wysłuchiwania konferencji ${ }^{10}$.

Do Polski bartolomici zostali sprowadzeni w 1683 r. przez Jana III Sobieskiego, który zetknął się z Instytutem w Wiedniu. Innocenty XI w 1680 r. wydał breve dla biskupa Wiednia, polecające opiece tego biskupa Instytut bartolomitów ${ }^{11}$.

O bartoszkach napisano: „Instytucja ta przyniosła nader wielkie korzyści w smutnej epoce trzydziestoletniej wojny, niesprzyjającej bynajmniej naukowemu i moralnemu rozwojowi duchowieństwa” ${ }^{2}$. Hugo Kołłątaj pisał: „Szkoły Bartoszków, w niczem się od akademickich nie różniły; to zgromadzenie księży świeckich, w społeczności żyjących, zatrudnia się w niektórych dyecezyach dozorem seminariów duchownych"13. Nie bez znaczenia jest, że założyciel bartolomitów zabraniał w instrukcjach dla kaznodziejów ostrych polemik z ewangelikami, a także: „wymyślać w kazaniach na Kalwina i Lutra”"14.

\section{Seminaria i szkoły bartolomitów}

Pierwszym prezesem polskich bartolomitów był archiprezbiter z Heilsbergu, Mateusz Ilmstat. Od początku swej bytności w Polsce bartoszkowie prowadzili seminaria duchowne. Do najstarszych należą seminarium diecezjalne w Warsza-

${ }^{8}$ Bartolomici 2, w: Encyklopedia kościelna, t. 2, red. M. Nowodworski, Warszawa 1873, s. $30-31$.

${ }^{9}$ Tamże.

${ }^{10}$ ADD, ZAKWZ, sygn. 11/Mon/1, Mowy konferencyjne. Rękopisy kazań o kapłaństwie ks. J. Jemility wygłoszonych w Węgrowie 1822-1824.

${ }^{11}$ Górka, Żywot i dzieła, s. 220.

${ }^{12}$ Bartolomici 2, s. 30-31.

${ }^{13}$ H. Kołłątaj, Stan Oświecenia w Polsce w ostatnich latach panowania Augusta III (17501764), Warszawa 1905, s. 52.

${ }^{14}$ Górka, Żywot i dzieła, s. 140. 
wie (1685-1846), Włocławku (1686-1691), w diecezji wileńskiej (1736-1765) ${ }^{15}$, Janowie Podlaskim (1685-1782), Łucku, Pińsku oraz seminaria własne Instytutu, obok węgrowskiego, w Brzeżanach, Górze Kalwarii, Karolinie ${ }^{16}$.

Swój rozwój w Polsce bartolomici zawdzięczają w dużej mierze akcji fundacyjnej prowadzonej przez wojewodę płockiego Jana Dobrogosta Krasińskiego. Od XVIII wieku głównym ośrodkiem bartolomitów w Polsce i miejscem rezydencji prezesa Instytutu był Węgrów, najlepiej uposażona prepozytura tej instytucji w Polsce. Jan D. Krasiński obdarzył ją licznymi nadaniami, a jednocześnie nałożył na księży Instytutu obowiązek prowadzenia szkoły i seminarium w Węgrowie. Akt fundacyjny parafii węgrowskiej podpisany został 14 października 1711 r. z inicjatywy J.D. Krasińskiego i obejmował również fundację prepozytury, mansjonarii oraz seminarium księży bartolomitów w Węgrowie ${ }^{17}$. Trzy dni później wojewoda płocki potwierdził wszystkie wcześniejsze nadania, powiększając je m.in. o zapisy na dobrach Rzewin w województwie płockim o wartości 60 tys. tynfów. Bartolomici zobowiązani byli do utrzymywania w prepozyturze siedmiu kapłanów, łącznie z prepozytem, oraz kształcenia w seminarium sześciu kleryków. W dniu 21 października 1711 r. biskup łucki Aleksander Benedykt Wyhowski zatwierdził powstanie parafii, mansjonarii i seminarium bartolomitów w Węgrowie ${ }^{18}$.

Siedzibą parafii był kościół farny w Węgrowie, ponadto bartoszkowie mieli obowiązek prowadzić filię parafii w Starejwsi (wówczas Stara Wieś), gdzie mieścił się ufortyfikowany pałac Krasińskich wystawiony jeszcze przez Radziwiłłów.

Nieruchomości parafii bartolomitów stanowiły w Węgrowie: kościół i plac, na którym stała świątynia, budynki probostwa oraz inne zabudowania o szerokości 143 łokci i długości 928 łokci, plac, na którym stał kościół Panny Marii przy ulicy wileńskiej wraz z cmentarzem, ogrodem zbożowym i gruntami ornymi oraz łąką, grunt przy drodze „teraz Ruchenka zwane”. Wieś Szaruty z gruntami, lasami, ogrodami i placami ${ }^{19}$. Było to rozszerzenie nadania z 1414 r., poczynionego przez wojewodę mazowieckiego Piotra Plika h. Rogala, który parafii węgrowskiej nadał 20 włók chełmińskich, ,na których wioska Szaruty została wybudowana"20.

Na dobrach jarnickich (Jarnice) plac, na którym stał kościół (obecnie stoi tam kościół przeniesiony z Budziszyna w 1819 r.) i cmentarz aż do rzeki Liwiec, stara plebania i ogród również ciągnący się do rzeki Liwiec, ,grunta i łąki zwane Oko-

${ }^{15}$ J. Gręźlikowski, Pierwsze seminaria duchowne w Polsce - recepcja dekretu Soboru Trydenckiego o seminariach, „Teologia i Człowiek”, 22 (2013) s. 78.

${ }^{16}$ Tamże, s. 30.

${ }^{17}$ ADD, ZAPW, sygn. III/Q/1, Fundatio Seu verius Melioratio Fundationis et Erectio Ecclesiae Praeposituralis Węgroviensis Anno MDCCXI.

${ }^{18}$ ADD, ZAPW, sygn. III/Q/1Erectio Fundationis Ecclesiae Praeposituralis Węgroviensis per Alexandrum de Wyhowo Wyhowski Episcopum Lucoriensem et Brestensem, Abbatem Siecichoviensem lata et promulgata. A. D. 1711, die 21 Octobris; M. Brudzisz, Źródta do dziejów Instytutu Księży Komunistów w Polsce znajdujące się w Archiwum Parafialnym w Węgrowie, „Archiwa, Biblioteki i Muzea Kościelne”, 21 (1970) s. 211-228.

19 Tamże.

${ }^{20}$ ADD, ZAPW, sygn. III/Q/1/B, Protokół (1845 r.), k. 3. 
py”21. W Starejwsi (ówczesna Stara Wieś) plac piaszczysty, na którym stał kościół, zabudowania plebani, szpital i ogród oraz liczne grunta plebańskie, a także grunty we wsi Kałęczyn ${ }^{22}$.

Ponadto probostwo węgrowskie miało zapisane „,sumy kapitulne"23. Suma 12000 złotych polskich zapisana na dobrach Węgrów i Ruchna przez Franciszkę z Krasińskich Wettyn ${ }^{24}$ w 1769 r., z procentem 0,05 rocznie. Na Starejwsi zapisano sumę 4000 złotych polskich z procentem 0,05 rocznie w $1767 \mathrm{r}$. i na tych samych dobrach jeszcze 1000 złotych polskich w 1777 r. Na dobrach jarnickich zapisano w $1800 \mathrm{r}$. sumę 4600 złotych polskich z procentem 0,05 rocznie oraz sumę 5777 złotych polskich i 23 i 1/4 grosza na majątku Jana Ossolińskiego (tj. Jana Onufrego Ossolińskiego, starosty drohickiego) z procentem rocznym 0,05 zapisaną w $1801 \mathrm{r}$.

Do tego dochodziło prawo pobierania dziesięcin zarówno w gotówce, jak i w naturze z majątków ruchnickiego, jarnickiego, węgrowskiego oraz prawo wyrębu drewna ${ }^{25}$, a także wspomniane już 60000 tynfów na dobrach Rzewin w województwie płockim. W zamian za to bartolomici byli zobowiązani do prowadzenia parafii, szkoły i seminarium duchownego ${ }^{26}$. Seminarium rozpoczęło działalność jeszcze przed 1715 r., zapewne równocześnie ze szkołą dla świeckich (młodzieży szlacheckiej). Szkoła świecka w Węgrowie posiadała najpierw dwie, a później trzy klasy. Jan D. Krasiński ufundował budynek (collegium) szkoły, zastrzegł także, że profesorem w szkole ma być kleryk, a nie świecka osoba.

Seminarium węgrowskie było seminarium własnym Instytutu i było praktycznie niezależne od biskupa, kształciło alumnów na potrzeby bartolomitów. Kolejne zapisy spowodowały powiększenie liczby kleryków z 6 do 12. Pierwszym regensem seminarium węgrowskiego został Michał Gass. Każdorazowo zostawał nim prepozyt węgrowski. W 1729 r. nowym prepozytem i tym samym regensem seminarium węgrowskiego został Michał Neyman.

W seminarium wykładało trzech profesorów, którzy uczyli filozofii i nauk teologicznych. W kolejnych latach alumni pobierali wykłady także z prawa kanonicznego i historii Kościoła ${ }^{27}$. W szkole dla młodzieży szlacheckiej profesorami było dwóch kleryków, nadzorowanych przez bartolomitę po święceniach kapłańskich. Kolegium bartoszków ze szkoły dwuklasowej, w której uczono gramatyki łacińskiej i niższych nauk, szybko przekształciło się w szkołę trzyklasową. W trzeciej klasie retoryki i poezji uczył już kapłan z Instytutu, będący jednocześnie pre-

${ }^{21}$ ADD, ZAPW, sygn. III/Q/1/B, Specyfikacja realności, sum kapitulnych, praw: jura et servituter probostwa węgrowskiego.

${ }^{22}$ Tamże, k. 2.

${ }^{23}$ Tamże, k. 3.

${ }^{24}$ Franciszka Krasińska poślubiła Karola Krystiana Wettyna, syna króla Augusta III Wettyna.

${ }^{25}$ Tamże, s. 4.

${ }^{26}$ A. Kołodziejczyk, Z dziejów węgrowskiej szkoły księży komunistów 1711-1833, „, Szkice Podlaskie", 5 (1996) s. 29.

${ }^{27}$ Tamże. 
fektem szkoły ${ }^{28}$. Na utrzymanie szkoły J.D. Krasiński przeznaczył 100 złotych polskich rocznie.

O wysokim poziomie zarówno seminarium, jak i szkoły dla świeckich węgrowskich bartolomitów świadczy fakt, że biskup Felicjan Konstanty Szaniawski fundując seminarium duchowne i szkołę w Kielcach, powierzył obie placówki właśnie bartoszkom węgrowskim ${ }^{29}$.

Regensem seminarium kieleckiego został bartolomita Andrzej Józef Karaś, który przybył do Kielc w 1723 r. Dotychczas był on wiceregensem seminarium warszawskiego. Biskup F.K. Szaniawski wydał akt erekcyjny seminarium w 1726 r., a 9 września 1727 r. seminarium kieleckie rozpoczęło działalność ${ }^{30}$. W 1729 r. regensem został prezes bartolomitów M. Gass, który od 1711 r. do końca 1728 r. był regensem seminarium w Węgrowie. Andrzej Karaś został wiceregensem i wiceprepozytem kolegiaty kieleckiej ${ }^{31}$.

Seminarium kieleckie kształciło początkowo 26 alumnów, a następnie zwiększono liczbę przyjętych seminarzystów do 36 . Połowę z nich stanowili klerycy diecezjalni, a połowę - bartolomici ${ }^{32}$. Księża z Instytutu zostali także osadzeni przy kolegiacie kieleckiej. Źródła archiwalne potwierdzają, że instytucja ta również w XIX wieku dbała o wysoki poziom moralny księży, którzy nadal przestrzegali obowiązku uczestnictwa w rekolekcjach kapłańskich ${ }^{33}$. O utrzymywaniu wysokiego poziomu nauczania również w XIX wieku świadczy fakt, że biskup kielecki Wojciech Górski szukał kandydatów na studia filozoficzne w Wiedniu właśnie wśród alumnów seminarium bartolomitów w Węgrowie ${ }^{34}$. W związku z reformą seminariów przeprowadzoną w zaborze austriackim w latach 1801-1802 władze żądały wysyłania na studia filozoficzne przynajmniej kilku alumnów z poszczególnych seminariów. W seminarium kieleckim brakowało wykładowców z filozofii, okresowo te braki zapełniali bartolomici, jednak w pierwszym rzędzie zapewniali kadrę we własnych seminariach. To powodowało, że kieleccy alumni nie byli w stanie zdać egzaminów wstępnych z filozofii w Wiedniu ${ }^{35}$. W związku tym biskup W. Górski zwiększył liczbę godzin wykładanej filozofii, co pozwoliło na podniesienie poziomu nauczania i tym samym alumni kieleccy byli $\mathrm{w}$ stanie zdać ten egzamin. Jednak w roku akademickim 1813-1814 w seminarium ponownie dały o sobie znać braki wykładowców filozofii i po raz kolejny wykłady z tego

${ }^{28}$ Tamże.

${ }^{29}$ ADD, ZAKWZ, sygn. III/Q/3, Akta Księży Wspólnego Życia dotyczące Seminarium Duchownego w Kielcach.

${ }^{30}$ J. Zdanowski, Seminarjum Duchowne w Kielcach. Szkic historyczny $w$ dwóchsetna rocznice założenia, Kielce 1927, s. 11-17.

31 Tamże.

${ }^{32}$ Górka, Żywot i dzieła, s. 227.

${ }^{33}$ ADD, ZAKWZ, sygn. 11/Mon/1, Mowy konferencyjne. Rękopisy kazań o kapłaństwie ks. J. Jemility wygłoszonych w Węgrowie 1822-1824.

${ }^{34}$ T. Wróbel, Nauczanie filozofii i teologii w kieleckim seminarium duchownym (1727-1962), „Nasza Przeszłość”, 59 (1983) s.101.

35 Tamże. 
przedmiotu przejęli bartolomici ${ }^{36}$. Były to tylko działania doraźne i bartoszkowie wykładający filozofię byli przenoszeni do seminarium kieleckiego rotacyjnie jako tymczasowe zastępstwo. Zgodnie z dekretem biskupa F.K. Szaniawskiego z 1726 r. głównym przedmiotem, który mieli wykładać księża z Instytutu Życia Wspólnego, była teologia moralna ${ }^{37}$. W XVIII wieku teologia moralna i prawo kanoniczne były traktowane jako jeden przedmiot. Zostały rozdzielone dopiero wspomnianą reformą austriacką z lat 1801-1802. Wykłady z teologii dogmatycznej bartolomici prowadzili, opierając się na podręcznikach jezuickich. Obowiązkiem wiceregensa było prowadzenie zajęć praktycznych z liturgiki i homiletyki. Po reformie z lat 1801-1802 wiceregens Józef Czekajowicz prowadził te zajęcia jako oddzielny przedmiot: pastorologia albo nauka pastoralna ${ }^{38}$.

Na przełomie XVIII i XIX wieku działali wybitni bartolomici jak: Kacper Zygmunt Wituński, Tomasz Józef Kamiński, F.E. Preiss (1727-1805) i F.K. Szaniawski (1768-1830). Kacper Z. Wituński ${ }^{39}$ był wykładowcą filozofii w seminarium kieleckim, archidiakonem kapituły kolegiaty kieleckiej, autorem podręcznika do filozofii dla alumnów kieleckich ${ }^{40}$. Tomasz J. Kamiński wykładał filozofię w seminarium w Kielcach i w Węgrowie, był autorem podręcznika filozofii dla alumnów ${ }^{41}$. Franciszek Preiss w 1759 r. wykładał teologię moralną w seminarium kieleckim, był autorem dzieł o charakterze apologetyczno-polemicznym, a od 1770 r. był jednocześnie proboszczem w Zagańsku ${ }^{42}$.

Franciszek Szaniawski nie tylko wykładał filozofię i teologię moralną w Seminarium Duchownym w Kielcach (1792-1793), ale i nauczał w świeckich szkołach wyższych m.in.: prawa cywilnego, kanonicznego i handlowego na Wydziale Prawa i Administracji na nowo otwartym Uniwersytecie Warszawskim (18161830). Był również pomysłodawcą utworzenia pierwszej szkoły prawa na ziemiach polskich, uważany jest też za prekursora badań porównawczych prawa. Od czerwca 1827 r. do lipca 1828 r. zarządzał archidiecezją warszawską jako wikariusz kapitulny. Był cenionym kaznodzieją i autorem publikacji o charakterze prawniczym ${ }^{43}$.

W 1820 r., gdy biskup Adam Prosper Burzyński erygował seminarium w Sandomierzu, jego tworzenie powierzył Klemensowi Bąkiewiczowi z Instytutu Księży Życia Wspólnego. Kolejni trzej regensi tego seminarium także byli bartolomi-

${ }^{36}$ Tamże, s. 101-102.

${ }^{37}$ Tamże, s. 110.

${ }^{38}$ Tamże, s. 123.

${ }^{39} \mathrm{Z}$ tekstu T. Wróbla trudno zrozumieć, czy uważa, że Z. Wituński był pierwszym regensem seminarium kieleckiego, czy za takowego uważa M. Gassa (Wróbel, Nauczanie filozofii i teologii, s.100). Jednak i w jednym, i drugim wypadku informacja ta jest błędna. Pierwszym regensem był Andrzej Józef Karaś, drugim - M. Gass.

${ }^{40}$ Wróbel, Nauczanie filozofii i teologii, s.100.

${ }^{41}$ „Concavum Philosophicum: Dialéctica (...) sub Thomae Kamiński professore et Lógica sub Lapidski professore in Domo Praepositurali Vęgroviensi traditae/...), scriptae per J. M. Wolynczewski Cler. Sem. in. Com. Viven. 1718-1719”. Por. Wróbel, Nauczanie filozofii i teologii, s.100.

${ }^{42}$ Por. Krześniak-Firlej, Firlej, Bibliografia piśmiennictwa, s. 209.

${ }^{43}$ Tamże, s. 226-227. 
tami. Jan Nepomucen Ratyński był regensem w latach 1820-1827, jednocześnie sprawował funkcję proboszcza w Łukawie pod Sandomierzem, a w 1823 r. został mianowany kanonikiem teologiem katedry sandomierskiej. W latach 1798-1800 wykładał filozofię i teologię moralną w seminarium kieleckim.

Jana N. Ratyńskiego w 1827 r. na stanowisku regensa zastąpił Józef Czekajowicz, który od 1799 r. był proboszczem kolegiaty kieleckiej i wiceregensem seminarium kieleckiego, gdzie wykładał teologię moralną. W dniu 3 maja 1799 r. został kanonikiem honorowym, a w 1808 r. archidiakonem katedry kieleckiej, oficjałem konsystorza generalnego i regensem seminarium kieleckiego. Od 1814 r. piastował funkcję proboszcza w Bodzentynie, jednak został pozbawiony funkcji regensa seminarium kieleckiego i archidiakona. Funkcję regensa seminarium sandomierskiego sprawował do 1830 r., kiedy to został zastąpiony przez K. Bąkiewicza. Ten ostatni był związany z Sandomierzem już od 16 grudnia 1809 r., gdy został instalowany na proboszcza (prepozyta) kolegiaty sandomierskiej. On też został regensem seminarium w 1820 r., jednak urząd ten sprawował zaledwie kilka miesięcy. Od 1840 r. był biskupem nominatem diecezji sandomierskiej. Zmarł 2 stycznia 1842 r. i został pochowany w podziemiach katedry sandomierskiej. Nie zdążył jednak przyjąć sakry biskupiej ${ }^{44}$. Oprócz regensów i wiceregensów także część kadry seminarium sandomierskiego rekrutowała się spośród bartoszków. Prawo kanoniczne wykładał bartolomita Jan Kalatowicz, który ukończył studia w Wiedniu, a do seminarium sandomierskiego przeszedł z Kielc ${ }^{45}$, gdzie wykładał teologię dogmatyczną oraz pastoralną, hermeneutykę i filozofię ${ }^{46}$.

Bartolomici prowadzili szkoły dla świeckich, nie tylko w Węgrowie i Kielcach. W 1745 r. Jan Klemens Branicki osadził w Białymstoku czterech bartolomitów, którym oddał drewniany budynek w celu prowadzenia przez nich szkoły i powiększył jej uposażenie, oddając na ten cel 30000 złotych polskich rocznie ${ }^{47}$. Rok później wybudował murowaną plebanię i osadził tam bartolomitów. W tej samej diecezji bartoszkowie mieli prepozyturę w Brzostwicy Wielkiej. W obu miejsowościach prowadzili parafię $e^{48}$. W $1750 \mathrm{r}$. Zofia Szaniawska przekazała im parafię w Wiszniewie ${ }^{49}$. W 1806 r. parafię w Białymstoku od bartolomitów przejęli księża misjonarze.

${ }^{44}$ Por. S. Kotkowski, Seminarium Duchowne w Sandomierzu w latach 1820-1926, Sandomierz 2010, s. 60-61.

${ }^{45}$ W. Wójcik, Nauczanie prawa kanonicznego w seminarium duchownym w Sandomierzu (1820-1970), „Prawo Kanoniczne : kwartalnik prawno-historyczny”, 15 (1972) z. 3-4, s. 106.

${ }^{46}$ Wróbel, Nauczanie filozofii i teologii, s. 119, 123, 128.

${ }^{47}$ A. Sztachelska, Białostocki ośrodek miejski w okresie działalności Jana Klemensa Branickiego, w: Studia i materiały do dziejów miasta Białegostoku, t. 4, red. H. Majecki, Białystok 1985, s.79.

48 J. Mandziuk, Zakony w (archi)diecezji wileńskiej, „Studia Teologiczne”, 5-6 (1987-1988) s. 173.

${ }^{49}$ G. Ryżewski, $Z$ dziejów dóbr Wiszniew w XV-XVIII wieku, „Białostockie Teki Historyczne”, 4 (2006) s. 96. 


\section{Kasata prepozytury węgrowskiej i likwidacja Instytutu na ziemiach polskich}

Instytut bartolomitów zakończył swoją działalność na ziemiach polskich w 1850 r. W Europie Zachodniej ostatnie seminarium bartolomitów, tzw. Bartholomeum, przeniesione w 1800 r. do Landsucht, zlikwidowano już w 1804 r. ${ }^{50}$.

W Encyklopedii kościelnej napisano dość enigmatycznie o upadku bartolomitów w Polsce:

Na nieszczęście z początkiem XVIII w. gorliwość bartolomitów poczęła w wie-

lu miejscach słabnąć, domy stopniowo upadały, a ich upadek tem był smutniej-

szy, im więcej sobie zjednali szacunku i poważania u wszystkich ${ }^{51}$.

Informacja ta jest daleka od prawdy. Wraz z początkiem XVIII wieku nastąpił rozwój bartolomitów w Polsce, a nie upadek. Większość opracowań, nie tylko polskich, podaje błędnie, że Instytut zakończył działalność w XVIII wieku ${ }^{52}$.

Tymczasem to właśnie na początku XVIII wieku J.D. Krasiński sprowadził ich do Węgrowa, to wtedy przejęli wspomniane seminarium w Kielcach, w XIX wieku byli regensami w seminarium sandomierskim. Nie ma też żadnych dowodów, aby likwidacja kommunistów w Polsce była związana ze spadkiem gorliwości w Instytucie, a raczej wynikała z sytuacji politycznej, a głównie z niechętnej postawy biskupów wobec bartolomitów. Jeszcze na przełomie XVIII i XIX wieku działali wspomniani wcześniej wybitni bartolomici. „Słabnącej gorliwości” bartoszków nie potwierdzają także źródła archiwalne. Z całą pewnością również w XIX wieku bartolomici przestrzegali zasady odbywania corocznych rekolekcji, które były na wysokim poziomie, co potwierdzają zachowane w Archiwum Diecezji Drohiczyńskiej (ADD) kazania ks. Jemility z Węgrowa ${ }^{53}$. Francis Merschman przyczyn upadku bartolomitów upatruje w działalności wrogów Instytutu ${ }^{54}$.

Na upadek bartoszków nie tylko w Węgrowie, ale jako całego Instytutu złożyło się kilka czynników. Niewątpliwie duże znaczenie miała sytuacja polityczna po upadku powstania listopadowego. Większe znaczenie miał jednak konflikt prezesów bartolomitów Andrzeja Zawadzkiego i Kacpra Jaworskiego z biskupem podlaskim Marcelim Gutkowskim. Mieczysław Żywczyński pisał o biskupie podlaskim:

Po zakończeniu wojny polsko-rosyjskiej w r. 1831 Gutkowski stracił do reszty sympatię społeczeństwa polskiego, odzyskał za to i ogromnie powiększył zaufanie do siebie rządu Paskiewicza. Okazał się najlojalniejszym z biskupów, Mikołajowi I najwierniejszym ${ }^{55}$.

${ }^{50}$ Górka, Żywot i dzieła, s. 225.

${ }^{51}$ Bartolomici 2, s. 30-31.

${ }^{52}$ Por. F. Merschman, Bartholomew Holzhauser, w: Catholic Encyclopedia, t. 7, New York 1913, s. 440; Kołłataj, Stan Oświecenia w Polsce, s. 52, p. 1; Bartolomici 2, s. 30-31.

${ }^{53}$ ADD, ZAKWZ, sygn. 11/Mon/1, Mowy konferencyjne. Rękopisy kazań o kapłaństwie ks. J. Jemility wygłoszonych w Węgrowie 1822-1824.

${ }^{54}$ Merschman, Bartholomew Holzhauser, s. 440.

${ }^{55}$ M. Żywczyński, Sprawa Gutkowskiego (1832-1839), „Rocznik Lubelski”, 1 (1958) s. 131. 
Konsystorz generalny diecezji podlaskiej 13 marca 1833 r. nakazał bartolomitom w Węgrowie przestrzeganie reskryptu carskiego o zakazie przyjmowania do seminarium powstańcó ${ }^{56}$. W lipcu 1833 r. władze zażądały od regensa Matlińskiego dostarczenia zaświadczeń od wójtów, że klerycy Felicjan Bartoli, Tadeusz Jabłoński i Mikołaj Panufnik nie brali udziału w powstaniu listopadowym. Owo żądanie obwarowano sankcją, że jeśli brali w nim udział lub nie dostarczą żądanych zaświadczeń, muszą zostać wydaleni z seminarium. Matlińskiemu za niedopełnienie swoichobowiązków groziło pozbawienieprawado egzaminowaniaiprzyjmowania kandydatów do seminarium ${ }^{57}$. Tadeusz Jabłoński został ponadto 17 października 1833 r. wezwany do okazania zaświadczenia o zwolnieniu ze służby wojskowej ${ }^{58}$.

Ograniczenia dotknęły także szkołę dla świeckich. W 1833 r. pozwolono bartolomitom na prowadzenie wyłącznie szkoły początkowej, pozbawiając jednocześnie części funduszy. Jednak zasadnicze znaczenie miała decyzja bpa M. Gutkowskiego, który sam będąc przeciwnikiem powstania listopadowego, nie wystąpił w obronie bartolomitów. Biskup nie tylko nie miał zamiaru bronić powstańców i bartoszków, ale z własnej inicjatywy wydał 27 listopada 1832 r. list pasterski do wiernych, w którym powstańców nazywał bezbożnikami ${ }^{59}$, a w represjach wobec bartolomitów posunął się dalej niż władze carskie i 9 kwietnia $1836 \mathrm{r}$. nakazał regensowi seminarium węgrowskiego Janowi Kantemu Matlińskiemu zamknąć seminarium w Węgrowie, a bibliotekę bartolomitów włączyć do biblioteki seminarium w Janowie Podlaskim ${ }^{60}$. Jednym $\mathrm{z}$ ostatnich alumnów seminarium węgrowskiego był Józef Dziarkowski, który przyjął świecenia kapłańskie w $1833 \mathrm{r}^{61}$ Następnie powrócił do Węgrowa, gdzie został nauczycielem w szkole dla świeckich ${ }^{62}$. W dniu 8 czerwca 1839 r. bp Gutkowski mianował proboszczem węgrowskim księdza diecezjalnego Petrycego Szaniawskiego ${ }^{63}$, tym samym parafia węgrowska została przejęta przez duchowieństwo diecezjalne.

Ostatni prezes bartolomitów Kacper Jaworski w 1840 r. wniósł skargę do Komisji Rządowej na decyzję biskupa podlaskiego, powołując się na zapisy J.D. Krasińskiego, które przyznawały beneficja nie parafii węgrowskiej, a bartolomitom,

${ }^{56}$ ADD, ZAKWZ, sygn. VII/CE/1, Korespondencja urzędowa księży wspólnego życia 16821861, k. 74.

${ }^{57}$ Tamże.

${ }^{58}$ Tamże.

${ }^{59}$ Żywczyński, Sprawa Gutkowskiego, s.131.

${ }^{60}$ AGAD, Centralne Władze Wyznaniowe Królestwa Polskiego (dalej: AGAD, CWWKP), sygn. 710, Akta tyczące się XX. Kommunistów i probostwa w Węgrowie z filią w Starej Wsi, w diecezji podlaskiej, k. 347.

${ }^{61}$ ADD, ZAKWZ, sygn. VII/CE/1, Korespondencja urzędowa księży wspólnego życia 16821861, k. 55.

${ }^{62}$ Kołodziejczyk, Z dziejów węgrowskiej szkoły, s. 41.

${ }^{63}$ AGAD, CWWKP, sygn..710, Akta tyczące się XX. Kommunistów i probostwa w Węgrowie z filią w Starej Wsi, w diecezji podlaskiej, [Do Jaśnie Wielmożnego Generała Adiutanta Szyopwa Dyrektora głównego prezydującego w Komisji Spraw Wewnętrznych i Duchownych], k. 151-152. 
jednocześnie warunkując owe beneficja prowadzeniem seminarium i szkoły ${ }^{64}$. Odrzucenie skargi K. Jaworskiego przez Komisję Rządową przypieczętowało koniec działalności bartolomitów w Węgrowie ${ }^{65}$.

Przeciwnicy bpa M. Gutkowskiego podnosili sprawę bartolomitów węgrowskich, których ten usunął bez upoważnienia papieża i wiedzy rządu ${ }^{66}$. Ten zarzut przeciw biskupowi przedstawiono w kurii rzymskiej. Wprawdzie działania hierarchy skutkowały likwidacją bartolomitów węgrowskich, jednak formalnie biskup ich nie usunął. Jego zabiegi przeciw bartolomitom nie były uzgodnione $\mathrm{z}$ rządem carskim, ponieważ bp M. Gutkowski od 1836 r. był z nim w konflikcie. Jednak jego działania były korzystne dla władz, więc Komisja Rządowa odrzuciła skargę złożoną przez K. Jaworskiego. Formalnie przeniesienie seminarium odbyło się za wiedzą i zgodą władz carskich, co więcej, nie zgłaszały żadnych uwag w tej sprawie, toteż skargi na biskupa były bezskuteczne. Jednak dla bartolomitów sprawy formalne nie miały większego znaczenia. Ich główna siedziba w Węgrowie została przez bpa M. Gutkowskiego pozbawiona podstaw funkcjonowania, a ostatecznie przejęta. Wprawdzie prezes Instytutu Księży Życia Wspólnego Andrzej Zawadzki (1832-1839) rezydował już w Wyszkowie nad Liwcem, jednak Węgrów nadal miał największe znaczenie dla bartolomitów. Utrata Węgrowa była silnym ciosem dla Instytutu, jednak nie zdecydowała o jego likwidacji w całej prowincji.

Należy zweryfikować funkcjonujący pogląd, że „gorliwość bartolomitów poczęła w wielu miejscach słabnąć" ${ }^{67}$. Przywoływane już wcześniej dokumenty z Archiwum Diecezji Drohiczyńskiej przeczą tej tezie. Również opinia J. Górki, że: „największą klęska dla naszych Bartoszków było to, że rząd rosyjski zagrabił wszystkie majątki kościelne" 68 , jest błędna. Instytut zasadniczo nie posiadał swojego majątku. Wyjątkiem były takie parafie jak Węgrów czy Wiszniew, gdzie faktycznie właścicielem dóbr byli bartoszkowie, ale w tym przypadku majątku pozbawił ich biskup, a nie rząd carski ${ }^{69}$. Księża bartolomici, o czym była mowa, byli osadzani na parafiach przez biskupa i dochody czerpali nie z majątku Instytutu, ale parafii, w której pracowali, zresztą często wspólnie z księżmi diecezjalnymi. Różnica polegała na tym, że księża bartolomici, w przeciwieństwie do księży diecezjalnych, dochody oddawali do wspólnej kasy. Z niej część była przeznaczona na utrzymanie księży, na seminaria, domy księży emerytów i jakąś część otrzymywali bartolomici do własnej dyspozycji (nie udało się ustalić, w jakich proporcjach następował podział dochodów). Pod względem materialnym bartoszkowie

${ }^{64}$ AGAD, CWWKP, sygn. 710, Akta tyczące się XX. Kommunistów i probostwa w Węgrowie z filią w Starej Wsi, w diecezji podlaskiej, [Prezes Księzy Kommunistów o utrzymanie prawa Zgromadzenia jakie mu stużą do prepozytury Węgrowskiej], k. 312-315.

${ }^{65}$ Kołodziejczyk, Z dziejów węgrowskiej szkoły, s. 51-42.

${ }^{66}$ Żywczyński, Sprawa Gutkowskiego, s.134.

${ }^{67}$ Bartolomici 2, s. 30-31; H. Ciereszko, Unia Apostolska Duchowieństwa Diecezjalnego Najświętszego Serca Jezusa, http://digital.fides.org.pl/Content/579/Unia_Apost_Duch.pdf (dostęp 02.07.2019).

${ }^{68}$ Górka, Żywot i dzieła, s. 231.

${ }^{69} \mathrm{~W} 1750 \mathrm{r}$. Zofia Szaniawska przekazała parafię w Wiszniowie bartolomitom i poczyniła zapisy, przekazując im na własność plebanię ,z gruntami i poddanymi”. 
różnili się od księży spoza Instytutu nie źródłem dochodów, a sposobem jego dysponowania. Oczywiście dla funkcjonowania Instytutu konieczne było posiadanie własnego seminarium, dla zachowania zaś autonomii Instytutu ${ }^{70}$, konieczne było posiadanie przynajmniej jednej niezależnej parafii, która byłaby siedzibą prezesa Instytutu.

Głównym powodem likwidacji Instytutu Księzy Życia Wspólnego na ziemiach polskich ${ }^{71}$ był konflikt z biskupami i kapitułami, nieuznanie przez biskupów ważności wyboru prezesa Instytutu ${ }^{72}$ i systematyczne odbieranie bartolomitom seminariów. Należy się zgodzić z J. Górką, że duże znaczenie miał także konflikt pomiędzy księżmi z Instytutu, a duchownymi spoza niego ${ }^{73}$. Potwierdza to przywoływany już list W. Janeckiego z 1824 r. osadzonego na wikariacie w kolegiacie kieleckiej obsługiwanej przez bartolomitów, w którym prosi o przyjęcie do instytutu, a jako powód prośby podaje: ,[...] aby [wikariusze bartolomici przyp. W.J.G.] do wspólnych dochodów przypuścić zechcieli i tym sposobem wszelkie intrygi i nienawiść osobista ustąpiła" ${ }^{4}$. Dokument ten potwierdza spostrzeżenie J. Górki, że bartolomitom zarzucano:

że z ich przyczyny powstają kłótnię i rozdwojenia wśród kleru, który dzieli się na Bartolomitów i Petrystów [księży, którzy są przeciwnikami życia wspólnotowego - przyp. W.J.G.], diecezje tracą jedność, a biskupi doznają trudności w wykonywaniu władzy ${ }^{75}$.

Co więcej prośba W. Janeckiego do prezesa bartolomitów:

[...] abyś raczył wydaną mi [tekst nieczytelny] na aktualnego wikariusza przy kolegiacie kieleckiej J. W. Biskupa krakowskiego potwierdzić nadesłaniem zwykłego Instrumentu Instytucji i poleceniem wikarym kieleckim aby mnie na wikariat tutejszy, jak zwykle, instalowali $[\ldots]^{76}$,

może budzić uzasadnione zastrzeżenie i niezadowolenie ze strony biskupa. Taka prośba o zatwierdzenie decyzji biskupa przez prezesa bartolomitów podważała władzę biskupa w jego diecezji.

Kacper Jaworski był ostatnim prezesem bartolomitów, którzy zakończyli

${ }^{70} \mathrm{O}$ pełnej niezależności od biskupów nie może być mowy. Konstytucje bartolomitów w wielu aspektach podporządkowywały księży z Instytutu decyzji biskupów.

${ }^{71}$ Bartolomici zostali zlikwidowani w Europie do końca XVIII wieku, poza Niemcami i Polską. Ziemie polskie były ostatnim miejscem, gdzie działali księża z Instytutu Życia Wspólnego. O likwidacji bartoszków w poszczególnych diecezjach decydowała głównie niechęć biskupów. Piotr Filip Dernbach, biskup Würzburga, zlikwidował bartolomitów w swojej diecezji już w 1679 r.

${ }^{72}$ Biskup Gutkowski w korespondencji z władzami rządowymi określa księdza Jaworskiego jako „mianującego się prezesem KK. Kommunistów w Królestwie Polskim nieznajdujących się” AGAD, CWWKP, sygn. 710, Akta tyczące się XX. Kommunistów i probostwa w Węgrowie z filią w Starej Wsi, w diecezji podlaskiej, k. 242.

${ }^{73}$ Górka, Żywot i dzieła, s. 231.

${ }^{74}$ ADD, ZAKWZ, sygn. VII/CE/1, Korespondencja urzędowa księży wspólnego życia 16821861, k. 28.

${ }^{75}$ Górka, Żywot i dzieła, s. 231.

${ }^{76}$ ADD, ZAKWZ, sygn. VII/CE/1, Korespondencja urzędowa księży wspólnego życia 16821861, k. 29. 
swoją działalność na ziemiach polskich w $1850 \mathrm{r}$. W tym czasie nie było już urzędu naczelnego prezesa (generała) Instytutu. Ostatnim, sprawującym ten urząd był Jan Krzysztof Hound, który zrzekł się funkcji przed $1770 \mathrm{r} .{ }^{77}$ Ostatecznym ciosem dla Instytutu na ziemiach polskich było nieuznanie przez biskupów wyboru prezesa bartolomitów K. Jaworskiego, chociaż był on wybrany legalnie przez kapitułę Instytutu ${ }^{78}$. W tej sytuacji bartoszkowie pozbawieni przez biskupów parafii, własnych seminariów, usunięci z seminariów diecezjalnych, a na koniec pozbawieni także prezesa przestali funkcjonować i to bez formalnej kasaty.

Po 1850 r. Instytut Księży Życia Wspólnego popadł w zapomnienie. Niektórych bartolomitów, którzy byli uznanymi wykładowcami i pisarzami, w ogóle nie identyfikowano z bartoszkammi, np. ks. F. Preiss, błędnie był przedstawiany jako (ex)jezuita ${ }^{79}$.

Nie wiadomo, jaka była liczebność Instytutu w Polsce, ale na podstawie danych $\mathrm{z}$ archiwum katedralnego w Moguncji o zmarłych bartolomitach można ustalić, że w Polsce w latach 1658-1790 zmarło 168 bartolomitów, na ogólną liczbę 1595 bartoszków zmarłych w tym czasie w całej Europie. Polscy komuniści stanowili więc $10,5 \%$ wszystkich bartolomitów ${ }^{80}$.

Likwidacja bartoszków dla Kościoła polskiego nie była odczuwalna w takim stopniu jak choćby XVIII-wieczna kasata jezuitów. Bartolomitów w seminariach zastąpili księża diecezjalni (często eksbartolomici) lub księża misjonarze. Zniesienie Instytutu było dotkliwe dla oświaty i kultury Węgrowa, ponieważ aż do 1918 r. nie było już żadnej szkoły średniej nie tylko w samym mieście, ale i okolicy ${ }^{81}$. Ciekawy wydaje się fakt, że likwidacja polskich bartolomitów zbiegła się w czasie z podejmowanymi na zachodzie Europy próbami wskrzeszenia instytutów życia wspólnego dla kleru diecezjalnego. Do idei Instytutu Księży Życia Wspólnego nawiązywał ks. Wiktor Lebeurier, zakładając w 1862 r. we Francji Unię Apostolską Kleru Najświętszego Serca Jezusa.

\section{REFERENCES / BIBLIOGRAFIA}

\section{Źródla archiwalne}

Archiwum Diecezjalne w Drohiczynie (ADD)

Zespół Akt Parafii Wniebowzięcia w Węgrowie (ZAPW)

sygn. III/Q/1/B, Kontrakt pomiędzy Janem Bonawenturą Krasińskim a Carlem Ceronim; sygn. III/Q/1ADD, Fundatio Seu verius Melioratio Fundationis et Erectio Ecclesiae Praeposituralis Wegroviensis Anno MDCCXI;

\footnotetext{
${ }^{77}$ Górka, Żywot i dzieła, s. 226.

${ }^{78}$ Tamże, s. 231.

${ }^{79}$ Por. Krześniak-Firlej, Firlej, Bibliografia piśmiennictwa, s. 209.

${ }^{80}$ Górka, Żywot i dzieła, s. 224. Merschman, Bartholomew Holzhauser, s. 440.

${ }^{81}$ Kołodziejczyk, Z dziejów węgrowskiej szkoły, s. 42.
} 
sygn. III/Q/1/B, Specyfikacja realności, sum kapitulnych, praw: jura et servituter probostwa wegrowskiego;

sygn. V/Fr/5, Księga sesji arcybractwa Trójcy Przenajświętszej przy kościele WNMP $w$ Wegrowie 1714-1783;

sygn. V/Fr/1, Księga sesji bractwa Św. Anny przy kościele Wniebowzięcia NMP w Węrowie w latach 1631-1934;

sygn. XIII/Y/1, Visitatio Generalis Ecclesiae Praposituralis et Parochialis Vengrowiensis.

Zespół Akt Księzy Wspólnego Życia w Węgrowie (ZAKWZ)

sygn. 11/Mon/1, Mowy konferencyjne. Rękopisy kazań o kapłaństwie ks. J. Jemility wygłoszonych $w$ Wegrowie 1822-1824;

sygn. III/Q/3, Akta Księży Wspólnego Życia dotyczące Seminarium Duchownego w Kielcach;

sygn. III/Q/1, Uposażenie i przywileje księży życia wspólnego dotyczace seminarium duchownego w Wegrowie, Kielcach $i$ Warszawie;

sygn. VII/CE/1, Korespondencja urzędowa księży wspólnego życia 1682-1861.

Archiwum Diecezjalne w Płocku

sygn. 5, Akta wizytacji archidiakonatu płockiego z 1598-1599 r.

Centralne Władze Wyznaniowe Królestwa Polskiego (CWWKP)

sygn. 710, Akta tyczace się XX. Kommunistów i probostwa $w$ Wegrowie z filia $w$ Starej Wsi, $w$ diecezji podlaskiej.

Archiwum Radziwiłłów, dz. VIII, nr 602.

\section{Opracowania}

Bartolomici, w: Encyklopedia kościelna, t. 2, red. M. Nowodworski, Warszawa 1873, s. 30-31.

Brudzisz Marian, Źródła do dziejów Instytutu Księży Komunistów w Polsce znajdujace się w Archiwum Parafialnym w Węrowie, ,A Archiwa, Biblioteki i Muzea Kościelne”, 21 (1970) s. 211-228.

Ciereszko Henryk, Unia Apostolska Duchowieństwa Diecezjalnego Najświętszego Serca Jezusa, http://digital.fides.org.pl/Content/579/Unia_Apost_Duch.pdf(dostęp: 02.07. 2019).

Górka Jakub, Żywot i dzieła wielebnego stugi bożego Bartłomieja Holzhausera, Tarnów 1908.

Gręźlikowski Janusz, Pierwsze seminaria duchowne w Polsce - recepcja dekretu Soboru Trydenckiego o seminariach, „Teologia i Człowiek”, 22 (2013) s. 63-84.

Kołodziejczyk Arkadiusz, Z dziejów węgrowskiej szkoły księży komunistów 1711-1833, „Szkice Podlaskie”, 5 (1996) s. 28-44.

Kotkowski Stanisław, Seminarium Duchowne w Sandomierzu w latach 1820-1926, Sandomierz 2010.

Krześniak-Firlej Danuta, Firlej Waldemar, Bibliografia piśmiennictwa zakonników z sekularyzowanych klasztorów działających na obszarze diecezji kieleckiej i sandomierskiej w XIX w., „Hereditas Monasteriorum”, 8 (2016) s.159-239.

Mandziuk Józef, Zakony w (archi)diecezji wileńskiej, „Studia Teologiczne”, 5-6 (19871988) s. 161-200. 
Mershman Francis, Bartholomew Holzhauser, w: Catholic Encyclopedia, t. 7, New York 1913, s. 339-440.

Wróbel Tomasz, Nauczanie filozofii i teologii w kieleckim seminarium duchownym (17271962), „Nasza Przeszłość”, 59 (1983) s. 97-163.

Zdanowski Józef, Seminarium Duchowne w Kielcach. Szkic historyczny w dwóchsetna rocznice założenia, Kielce 1927.

Żywczyński Mieczysław, Sprawa Gutkowskiego (1832-1839), „Rocznik Lubelski”, 1 (1958) s. 129-146.

\title{
THE BARTHOLOMITES' EDUCATION IN POLAND, ON THE EXAMPLE OF THE SEMINARIES IN WEGROW, KIELCE AND SANDOMIERZ. AN OUTLINE OF ISSUES
}

\begin{abstract}
The founder of the institute of common life for priests known as Bartholomites, bartoszkowie or communists, whose constitutions were approved on 7 July 1680 by Innocent XI, was Bartholomew Holzhauser. What set the institute apart from others was the establishment of seminaries and a great care for the quality of education of the alumni. The Bartholomites were brought to Poland by king John III Sobieski. The Jan Dobrogost Krasiński Foundation for Bartholomites in Wegrow made the city the centre of the institute's activities. The majority of the staff teaching in the Kielce seminary came from the Wegrow Bartholomite seminary, and in the 19th century the Bartholomites from the Kielce seminary constituted the core of the newly created Sandomierz seminary. The institute of common life for priests finished its activity in the middle of the 19 th century.
\end{abstract}

Keywords: Bartholomites; institute of common life for priests; theological seminary; Wegrow 